\title{
Caminhando com Antonio
}

Egon Heck*

Nas trilhas do indigenismo e Academia, na solidariedade e indignação, sempre de coração e mente abertos na doação incondicional à vida e ao saber, mas, acima de tudo, com muito amor, eficiência e determinação.

Esse foi o Antonio que conheci no caminho e com o qual partilhei momentos importantes, como amigos sinceros e leais na luta pelos povos indígenas e pela justiça. Isso desde o início da década de 70 até a sua derradeira viagem; um caminho que continuamos trilhando, agora na memória carinhosa, de quem partilhou caminhos e sonhos, lutas e esperança.

Nós nos conhecemos na Operação Anchieta, posteriormente, Operação Amazônia Nativa (OPAN). Ele, estudante seminarista jesuíta, e eu, da Diocese de Chapecó. Nosso lugar de encontro foi a causa indígena. Fomos atraídos a essa causa por estudantes jesuítas, rebeldes e não conformados com o estilo de presença missionária então em curso nas missões tradicionais e, ao mesmo tempo, conhecedores da realidade indígena no sul do Brasil (Kaingang, Guarani , Xokleng, Xetá e Terena). Buscavam abrir novos horizontes no compromisso junto aos povos indígenas. Criaram então um grupo a partir dos jesuítas e de leigos. Antonio e eu nos encontramos nesse caminho de busca rebelde e solidariedade incondicional aos pobres, em especial dos povos indígenas, na perspectiva de transformação e criação de uma nova sociedade.

“- Vamos ver a bomba que vem hoje", dizia Antonio, com passos apressados em direção à banca de jornal mais próxima. Estávamos em agosto de 1988, na reta final do processo constituinte. O jornal O Estado de São Paulo, foi porta-voz de uma das mais sórdidas e amplas campanhas já desencadeada na história recente desse país, contra uma instituição, visando impedir os direitos indígenas na nova Constituição. O CIMI foi então submetido a uma Comissão Parlamentar Mista de Inquérito, no Congresso. Antonio, como secretário do CIMI, junto com seus colegas em Brasília e por esse país afora, sofremos

* Conselho Indigenista Missionário (CIMI).
Tellus, ano 12, n. 23, p. 247-249, jul./dez. 2012

Campo Grande, MS 
muito. Foi necessário muita paciência histórica, discernimento e determinação para enfrentar os dragões da mineração em aliança com outros setores das elites dominantes. Lembro-me das noites praticamente em claro, em que tínhamos que pensar o que fazer para reverter os estragos à bela e audaz luta e caminhada dos povos indígenas na Constituinte. Antonio foi fundamental nesse momento crucial para a história e os direitos dos povos indígenas no Brasil.

\section{Início de caminho}

Eu conheci Antonio em Porto Alegre, no início da década de setenta, no caminho da OPAN. Sobre esse momento, escreveu Egydio Schwade, recentemente, contando os primórdios da organização, com a publicação de uma série de artigos sobre a dramática situação dos índios no Rio Grande do Sul e da presença de Antonio Brand:

A série de artigos agitou também o Noviciado dos jesuítas e recebi uma carta de Antonio Brand e Ivo Schroeder, na qual eles se dispunham a fazer pesquisa semelhante a que Thomaz e eu havíamos feito no RS em aldeias do Leste Catarinense durante as suas férias de 1968. Trouxeram assim à luz a realidade indígena dos índios Xokleng e Guarani do Vale do Itajaí. (Egydio, fevereiro 2013).

Na mesma narrativa, Egydio fala da importância de Antonio, na coordenação da OPAN, desde 1972:

Insisto na presença de Antônio na coordenação da OPAN, porque a sua ação ali, como a de muitos de seus colegas leigos foi fundamental no primeiro impulso à renovação da política indigenista da Igreja Católica dentro dos princípios delineados pelo Concílio Vaticano II.

Destaca as dificuldades de bispos e padres em promover mudanças mais profundas. Enquanto isso,

Antonio Brand, Ivo Schroeder, Darci Secchi, Ivar Busatto, Egon Heck e Gunter Francisco Loebens deixavam suas respectivas instituições e para com colegas leigas puxarem a fila de um grupo de jovens que se engajavam na perspectiva da visão conciliar da Igreja, não Instituição, mas povo de Deus.

\section{Antonio e a luta dos povos indígenas em Mato Grosso do Sul}

No duro e difícil caminho dos Kaiowá Guarani, reencontrei-me com Antonio, em Campo Grande. Nos últimos sete anos, partilhei com ele, não tanto o caminho acadêmico, onde foi dinâmico e brilhante, na UCDB e além dela, mas nos duros embates e lutas que travam os Kaiowá Guarani. Se ele 
estivesse conosco hoje, certamente lhe partiria o coração ver o jovem Denílson ser executado, na região onde passou muitos e fortes momentos de sua vida de solidariedade e incondicional apoio às lutas dos Kaiowá Guarani, com projetos específicos de apoio a esse povo, especialmente através do NEPPI, do qual foi um dos fundadores e era coordenador.

Sua paixão pela causa do povo Kaiowá Guarani o fez não apenas se aprofundar no conhecimento da história e luta desse povo, mas o fez amá-lo profundamente, tornando-se dele inseparável. O apoio irrestrito à dura caminhada vem desde 1978, quando foi morar na Vila São Pedro, em Dourados, tornando-se o iniciador e coordenador do CIMI Regional, MS.

Tornou-se um dos maiores conhecedores do povo guarani, em especial dos Kaiowá e Nhandeva, em Mato Grosso do Sul, aos quais dedicou sua vida. Quando uma situação de extrema violência e ameaçadora emergia, lá estava o Antonio articulando aliados, nos mais diversos setores, buscando encontrar forças suficientes para o enfrentamento em favor dos povos indígenas. Sua casa transformava-se num espaço de articulação e resistência.

Nas longas rodadas de chimarrão, conversávamos muito sobre a dramática situação Kaiowá Guarani e Terena. Construímos algumas propostas para iniciar o processo de reconhecimento e devolução das terras e territórios desses povos. Com hábil diplomacia, mas também com a radicalidade que a realidade exigia, ele levava propostas e as defendia com determinação e serenidade nos mais diversos espaços, nacional e internacionalmente. Conhecia como ninguém esse povo, e isso o fez amar e se comprometer com a vida e futuro dos Kaiowá Guarani.

Com esse grande amigo continuo a caminhada, agora em dimensões diferentes. 
